\title{
Patenting Human Evolution
}

\author{
Dr. Andrew W. Torrance
}

\section{INTRODUCTION}

Genetic engineering is an utterly transformative technology. It allows humans to alter genomes with both immediacy and precision, creating as its product organisms possessing novel combinations of genes. Where multiple generations of selective breeding of pets, livestock, and crops have long yielded organisms whose genes suited them well to human purposes, such as tameness, obedience, protein content, and higher yields, genetic engineering offers the prospect of deliberate alteration of specific genes in a single generation. Rather than the continuous genetic change over time achievable through artificial selection, genetic engineering enables genetic change to be discontinuous and disjunctive by allowing any gene from any source organism, or even synthesized de novo, to be inserted into the genome of any other organism. Although many novel combinations of genes may turn out to be deleterious to their new hosts, successful combinations may create organisms with radically new suites of genetic characteristics. Such organisms could now, and, in the future, most probably will, include genetically "enhanced" humans. ${ }^{1}$

Genetic engineering is broadly legal in the United States, although federal funding may be restricted for certain applications in humans. ${ }^{2}$ Currently, the patent system presents a significant legal restriction on

Dr. Andrew W. Torrance is an Associate Professor at the University of Kansas School of Law and a Research Associate at the Biodiversity Institute at the University of Kansas. Dr. Torrance received his Ph.D. in biology from Harvard University and his J.D. from Harvard Law School. The author wishes to thank Alison Dunehoo and Jonathan Grossman for their invaluable research assistance, and Professors Henry T. Greely and Peter Barton Hutt, Calestous Juma, John Dowling, and Dean Jim Chen for their encouraging comments on early versions of this article.

1. This article uses the descriptors "enhance" and "enhancement" sensu Henry T. Greely. See, e.g., Henry T. Greely, Regulating Human Biological Enhancements: Questionable Justifications and International Complications, 4 SANTA CLARA J. INT'L L. 87, 105 (2006) (concluding that human biological enhancements and other kinds of human enhancement are not justifiably different).

2. For example, federal funds are unavailable to support research on human cloning, which can involve somatic cell nuclear transfer, a process likely to facilitate human genetic enhancement. LEE SiLver, REMAKING EDEN: How GENETIC ENGINEERING AND Cloning WILL TRANSFORM THE AMERICAN FAMILY 152 (1998). 
human genetic engineering because it invests patent owners, including those whose patents claim newly discovered or synthesized genes, with powerful rights to exclude others from making, using, offering to sell, or selling patented genes within the United States, or importing patented genes into the United States. ${ }^{3}$ Biotechnology owes much of its prodigious progress to the availability of patent protection for genes and their polypeptide products. Since the United States Supreme Court held that genetically modified eubacteria constitute patentable subject matter, ${ }^{4}$ private enterprise and public institutions, such as universities and government research institutes, have discovered and patented myriad genes. Patent protection is a keystone asset of pharmaceutical and biotechnology companies. In fact, some have argued that the main product of the biotechnology industry - which, as a whole, has yet to turn a profit - is not medicines per se, but patents claiming medicines or methods of making them. ${ }^{5}$ Availability of patent protection for genes has generally been assumed to promote innovation in genetics. Thus, the patent system may promote the discovery and synthesis of relatively more new genes while simultaneously limiting access to those new genes; by extension, the patent system may promote more raw material for human genetic enhancement while simultaneously limiting access to its applications.

Until very recently, the major hurdle facing any human who desired to have biological children was attracting a fertile mate. While selecting the traits of one's children remains an exercise in imprecision even today because of limitations in our understanding of and ability to manipulate genes, biotechnology now offers the prospect of precise selection of almost any individual, expressible trait encoded by one or more genes. Human evolution stands on the verge of becoming fine-tuned and deliberate where it had previously been gross-grained, greatly unpredictable, and without ultimate direction. As the title of a leading book on human genetic enhancement suggests, human evolution is currently embarking on a transition "From Chance to Choice.",

By allowing gene patent owners to control, at least to a significant extent, the ability of parents to choose the traits of their offspring, the patent system enables private policing of a technology with strong

3. 35 U.S.C. § 271(a) (2000).

4. Diamond v. Chakrabarty, 447 U.S. 303, 309 (1980).

5. See, e.g., John M. Golden, Biotechnology, Technology Policy, and Patentability: Natural Products and Invention in the American System, 50 EMORY L.J. 101, 168-70 (2001).

6. Allen Buchanan, Dan W. Brock, Norman Daniels \& Daniel Wikler, From Chance To Choice: Genetics \& Justice (2000). 
implications for the evolutionary future of humanity. Under a patent regime, parents would normally have to obtain permission before they could ensure that their children possessed patented genes encoding the enhanced traits desired by those parents. Permission would likely require payment. Though some genes will already be in the public domain, and others will continually come off patent, many genes will be the subject of patent claims. Indeed, as discoveries of new genes and technologies for de novo design of synthetic genes improve, as they are likely to do at an ever-accelerating rate, especially advantageous genes may become available to parents in the genetic enhancement marketplace. As they do, the race to genetically enhance one's children will proceed apace.

Part II of this Article introduces the biology of evolutionary change. Part III discusses the current state of genetic engineering and its potential application to human genetic enhancement. Part IV discusses the legal contours of proprietary patent protection for, and access to, genetic innovations.

This Article explores legal, policy, and societal implications that the patent system may hold for regulating human genetic enhancement. It argues that public policy must grapple with these implications before current technological possibilities become societal realities. The choices society makes about how to regulate access to human genetic enhancement could have important implications even for the future trajectory of human evolution.

\section{EVOLUTION}

\section{A. Early Evolution}

Biologists estimate that life on earth first arose more than four billion years ago. In its earliest form, life was probably little more than a simple single cell composed of a phospholipid cell membrane that housed a mixture of just enough simple nucleic acids, proteins, carbohydrates, and lipids to allow the cell to carry out basic survival functions, such as metabolism, and to make faithful copies of itself. Over time, in response to both the natural selection imposed by environmental conditions and random genetic drift, this unicellular organism and its offspring gave rise to every lineage of life on earth, from microscopic archaea and eubacteria to gargantuan sequoias and whales to humans.

Some lineages of life met their demise through extinction. Others gave rise to additional lineages that persist into the present day. Surviving lineages include organisms spanning the range of physical size 
from single cells to multiple cells to billions of cells. Evolutionary success can be measured by any number of criteria, such as evolutionary radiation (i.e., the number of relatively closely related lineages), location within a trophic web (i.e., who eats whom), longevity, physical size, speed, complexity of social behavior, or cognitive capacity. However, the ultimate measure of evolutionary success is survival and reproduction into the next generation. If a lineage has persisted into the present day, it is more successful than those lineages already extinguished by the mere fact of its continued existence, and its unbroken ability to transmit its genes from past to future generations.

\section{B. Human Evolution}

Modern humans are genetically very different from their ancient human ancestors. Over the past five to ten million years an evolutionary lineage arose in Africa and acquired, among many other distinctive characters, bipedal gait, a brain very large relative to body size, and highly complex social behavior. This lineage - the humans -includes modern Homo sapiens, the single extant species of the family Hominidae. Over the course of human evolution, ancestors of modern humans underwent radical changes in morphology (e.g., body, head, foot, hand, and pelvis shape and size), physiology (e.g., hidden estrus), and behavioral ecology (e.g., grammatical and symbolic language and tool use).

A widespread assumption exists that modern humans have ceased evolving. Some derive this conclusion from religion, many varieties of which view humans as the apogee, or even the perfected final product, of biological evolution. ${ }^{7}$ Others posit that human technological mastery of the natural world has allowed humanity to sidestep nature "red in tooth and claw," $"$ avoiding the effects of natural selection entirely, and has "stopped human evolution cold." Still others suggest that cultural evolution, ${ }^{10}$ which can act much more quickly than biological

7. Of course, some religions include beliefs that are inconsistent or incompatible with the very existence of biological evolution.

8. Alfred LORD TENNYSON, In MEMORIAM A.H.H. (1850). Tennyson's phrase "red in tooth and claw" has been borrowed to summarize the behavior of all living things arising out of the survival-of-the-fittest doctrine. E.g., RICHARD DAWKINS, THE SELFISH GENE 2 (1999).

9. Stephen R. Palumbi, the Evolution Explosion: How Humans Cause Rapid EVOLUTIONARY CHANGE 211 (2001).

10. Also known as exo-somatic evolution and technological evolution. RICHARD DAWKINS, The AnCestor's TAle: A Pilgrimage to the DaWn of EVOlution 26 (2004). 
evolution, ${ }^{11}$ has displaced biological evolution as the dominant force molding humanity, and that, while human ideas may evolve, human genes no longer do.

Even some biologists have sounded the demise of human evolution. Julian Huxley, for example, suggested that "the more elaborate social life is, the more it tends to shield individuals from the action of natural selection." "12 Stephen Palumbi has outlined the hypothesis of human evolutionary stasis as follows:

When we provide medical treatment to the injured, give food to the hungry, replace brute muscle with John Deere tractors - the argument goes - we prevent selection from weeding out a myriad of weak or physically imperfect individuals. Because we can clothe ourselves in winter, feed ourselves from storehouses during droughts, predict tsunamis and the paths of hurricanes - the argument continues - we break the link between physical variation among different humans and differences in reproductive success. ${ }^{13}$

However, actual biological evidence suggests that evolution by natural selection still strongly affects humans. ${ }^{14}$ Technological development has "failed to halt human physical evolution." 15 Although some of the natural selective forces acting to change human genotypes and phenotypes may have changed (e.g., predation by other large organisms certainly plays a much lesser role than it once did), humans continue to evolve today.

\section{Evolution and Genes}

Darwin's theory of evolution by natural selection depends upon three observations about the natural world:

(1) "All organisms tend to produce more offspring than can possibly survive" in a world of limited resources; ${ }^{16}$

(2) Offspring tend not to be identical, but tend to vary among themselves;

\footnotetext{
11. Id.

12. Palumbi, supra note 9, at 209 (quoting Julian HuXley, Evolution In ACtion (1953)).

13. Id.

14. Id. at 211-30.

15. Id. at 211 .

16. Stephen Jay Gould, Full House: The Spread of Excellence from Plato to DARWIN 138 (1996).
} 
(3) At least some of this variation is inherited by future generations.

As an inference from observations (1)-(3):

[O]n average (as a statistical statement, and not in every case) survivors will tend to be those individuals with variations that are fortuitously best suited to changing local environments. Since heredity exists, the offspring of survivors will tend to resemble their successful parents. The accumulation of these favorable variants through time will produce evolutionary change. ${ }^{17}$

All organisms are subject to natural selection, including humans. Despite apparent mastery of many aspects of their environment, human evolution continues with every new generation.

Evolution in its most general sense simply means change over time. Biological (or organic) evolution (hereafter simply "evolution") refers to "[g]enetic changes in lineages of organisms over time. Through this process, a lineage may split and diversify into new species."18 Evolution is universal. It occurs in every lineage. While there may be an implicit assumption, especially beyond the scientific communities, that evolution is something that happens only to organisms other than humans, it would be remarkable, and extremely improbable, if human evolution were to cease. Evolution is continuous. Though rates of evolution certainly fluctuate, whether due to natural selective challenges or to mere stochasticity, genetic changes in lineages of organisms march ever onwards. Even humanity experiences continuous genetic changes over time.

Evolution can occur rapidly. Though some evolutionary changes take long periods of time, rates of evolutionary change need not be slow. Numerous examples exist of rapid evolution within populations of microbes. Perhaps the most prominent example of rapid microbial evolution is the emergence of antibiotic resistance among some infectious eubacteria, such as Staphylococcus aureus, Streptococcus pneumoniae, and Salmonella spp. ${ }^{19}$ Rapid evolution has also been observed in much larger multicellular organisms, such as insects. ${ }^{20}$ However, even vertebrates appear capable of rapid evolution. A series of studies of Anolis lizards on Caribbean islands by Jonathan Losos'

\footnotetext{
17. Id.

18. Tree of Life Glossary, http://tolweb.org/tree/home.pages/glossary.html\#evolution (last visited Oct. 8, 2008).

19. See generally, Robert Verne Miller \& Martin J. Day, Microbial Evolution (2004).

20. See, e.g., Raymond B. Huey, et al., Rapid Evolution of a Geographic Cline in Size in an Introduced Fly, 287 SCIENCE 308 (2000).
} 
research group have challenged assumptions that vertebrate evolution requires many generations and long periods of time. ${ }^{21}$ Based on an empirical study tracking evolutionary change in Anolis sagrei lizards found on six small Bahamian islands, Losos' group observed:

Because of its potentially epochal scope, evolutionary biology is often caricatured as a strictly descriptive science, but recent years have shown that evolution can be studied on short time scales and that evolutionary biology can be both experimental and predictive.... [W] showed that selection dramatically changed direction over a very short time, within a single generation, favoring first longer and then shorter hindlimbs. The behavioral shift from the ground to higher perches of smaller diameter apparently caused this remarkable reversal; behavioral flexibility, indeed, may often be the key in driving extremely rapid reversals in evolution. ${ }^{22}$

Evidence also exists for rapid evolution of humans. ${ }^{23}$

"Evolution is the result of accumulated changes in the composition of the gene pool." ${ }^{24}$ Biological evolution is genetic change in a lineage of organisms over generations. ${ }^{25}$ A genotype is the "genetic constitution, latent or expressed [or] the sum total of all the genes present in an individual." "Genetic information is encoded in the sequence of nucleotides in molecules of DNA, and these, in turn, determine the sequence of amino acids in molecules of protein." 27 A phenotype is the "physical appearance of an organism." 28 The phenotype of an organism "results from the interaction between the genetic constitution (genotype) of the organism and its environment." 29

An organism's genes encode information used in the synthesis of molecules that construct the organism, maintain its various functions,

21. See, e.g., Jonathan B. Losos, et al., Rapid Temporal Reversal in Predator-Driven Natural Selection, 314 SCIENCE 1111 (2006).

22. Id. (citations omitted).

23. See generally Gregory Clark, A Farewell to Alms: A Brief ECONOMic History of THE WORLD (Joel Mokyr ed., 2007) (This controversial book includes a hypothesis that the population of Britain underwent rapid genetic change during and after (and possibly in response to) the Industrial Revolution.).

24. Peter H. Raven et Al., Biology of Plants 258 (6th ed. 1999).

25. A number of scholars have posited the importance of cultural evolution as a complement, or sometimes an alternative, to biological evolution. See, e.g., DAwKINS, supra note 10. However, such cultural evolution was most likely made possible by underlying biological evolutionary changes, such as increases in brain size and complexity.

26. RAVEN ET AL., supra note 24 , at 898.

27. Id. at 231 .

28. Id. at 905 .

29. Id. 
and form the physical embodiment of the organism. Biological evolution occurs when different gene variants ("alleles") change their relative frequencies in populations of organisms over time:

In natural populations, some alleles increase in frequency from generation to generation, and others decrease. (The frequency of an allele is simply the proportion of that allele in a population in relation to all the alleles of the same gene.) If an individual has a favorable combination of alleles in its genotype, it is more likely to survive and reproduce. As a consequence, its alleles are likely to be present in an increased proportion in the next generation. Conversely, if the combination of alleles is not favorable, the individual is less likely to survive and reproduce. Representation of its alleles in the next generation will be reduced or perhaps eliminated. Evolution is the result of such accumulated changes in the gene pool over time. ${ }^{30}$

Genotypic change over time produces phenotypic change over time.

Evolution does not progress towards any particular goal, destination, or end-point (except, in some cases, extinction). Evolutionary change proceeds by the "accumulation of . . favorable variants through time." 31 Natural selection favors the survival and reproduction of those organisms that happen to be better adapted to their local environments. However, local environments tend to change. This leads to constant adaptation for survival, rather than progress:

If a sequence of local environments could elicit progressive advance through time, then some expectation of progress might be drawn from natural selection. But no such argument seems possible. The sequence of local environments in any one place should be effectively random through geological time - the seas come in and the seas go out, the weather gets colder, then hotter, etc. If organisms are tracking local environments by natural selection, then their evolutionary history should be effectively random as well.

These arguments led Darwin to his denial of progress as a consequence of the "bare bones mechanics" of natural selection-for this process yields only local adaptation, often exquisite to be sure, but not universally advancing. ${ }^{32}$

\footnotetext{
30. Id. at 239 .

31. GouLD, supra note 16 , at 138.

32. Id. at $139-40$.
} 


\section{Deliberate Evolution}

Evolution by natural selection is not the only form of evolution that Charles Darwin observed. In fact, he transposed principles of animal and plant breeding, which is known as "artificial selection," to understand how natural selection might function to drive biological evolution. Darwin was struck by the rapidity and magnitude of the biological change allowed by artificial selection:

We cannot suppose that all the breeds were suddenly produced as perfect and as useful as we now see them; indeed, in several cases, we know that this has not been their history. The key is man's power of accumulative selection: nature gives successive variations; man adds them up in certain directions useful to him. In this sense he may be said to make for himself useful breeds.

The great power of this principle of selection is not hypothetical. It is certain that several of our eminent breeders have, even within a single lifetime, modified to a large extent some breeds of cattle and sheep.

Darwin concluded that, to alter genotypes and phenotypes, "the accumulative action of Selection . . . is by far the predominant Power." "34

The Tibetan Yak provides a vivid illustration of the fundamental changes to an organism's biology that artificial selection can make, in this case "artificial selection over the centuries that Tibetans have depended on them." 35 Because of human selection, Tibetan yaks have become superbly suited to existence in the mountains of Tibet:

Over the generations, Tibetan yaks have become so adapted to high altitudes they suffer poor health under 10,000 feet. Their coarse hair, hanging in ragged insulating cascades, combines with other features of their physiology to protect them from the rigors of the Himalayas. They have immense lungs - three times larger than similar-sized cows - to pull oxygen from the miserly air. They have less hemoglobin in their red blood cells, and indeed fewer red blood cells, than their lowland relatives. This thin blood allows for a higher ability to withstand temporary dehydration in the dry air and prevents blood cells from being forced out of ruptured capillaries by the high blood pressure required in high-altitude environments. Even the microstructure of

33. Charles Darwin, ON THE ORIGIN OF SPecies 30-31 (Harvard Univ. Press 1964) (1859)

34. Id. at 43 .

35. PALUMBI, supra note 9, at 178. 
their lungs differs. Yaks have thin-walled arterioles in their lungs, allowing better transport of oxygen into their bloodstream. ${ }^{36}$

Many of these adaptations are extreme, allowing Tibetan yaks to exist in habitats and achieve results their ancestral yaks could not. In fact, so extreme are some of their adaptations that Tibetan yaks have secondarily lost the ability to thrive at lower altitudes.

Humans too have evolved adaptations to their peculiar ecological niche. Like the Tibetan yak, many of these adaptations have a genetic basis.

\section{HUMAN GENETIC ENHANCEMENT}

\section{A. Genetic Engineering}

Genetic engineering allows the goals of artificial selection to be achieved more efficiently than traditional selective breeding programs. By inserting genes into the genome of an organism, such as a human, traits of that organism could be altered precisely and immediately within a single generation.

Genetic engineering, or recombinant DNA technology, encompasses a set of chemical methods by which means the "genetic endowment of organisms can now be precisely changed in designed ways."37 Genetic engineering "allows selected individual genes to be transferred from one organism into another, including genes from unrelated species." ${ }^{38}$ Genetic engineering includes transgenics (transferring genes from organism to organism), genetic alteration (altering genes within the existing genome of an organism), and cloning (creating a genetic duplicate of an existing organism, and then, optionally, altering the genome of that organism). Although genetic engineering has heretofore relied largely upon existing genes, advances in the techniques of synthetic biology offer the imminent prospect of synthetic genes, and entire genomes, designed and synthesized de novo. ${ }^{39}$

\footnotetext{
36. Id.

37. JEREMY M. BERG ET AL., BIOCHEMISTRY 134 (6th ed. 2007).

38. Nuffield Council on Bioethics, The Use of Genetically Modified Crops in Developing COUNTRIES: A FOllow-Up Discussion PAPER 5 (2004), available at http://www.nuffieldbioethics.org/fileLibrary/pdf/GM_Crops_Discussion_Paper_2004.pdf [hereinafter NUFFIELD COUNCIL].

39. See, e.g., Daniel G. Gibson et al., Complete Chemical Synthesis, Assembly, and Cloning of $a$ Mycoplasma genitalium Genome, 319 SCIENCE 1215 (2008). In fact, this work has already formed the basis for U.S. Patent Application No. 11/635,355, entitled "Synthetic Genomes," which claims multiple variations on "[a] method for constructing a synthetic genome," "[a] synthetic genome,"
} 
As long as there has been agriculture, humans have deliberately modified the genetic material of their crops and livestock through selectively breeding for desired genetic traits. Genetic engineering "can be used to promote a desirable... character or to suppress an undesirable trait, ${ }^{40}$ and has allowed genetic modification to be achieved more precisely, efficiently, and rapidly than previously possible. Genetic engineering allows the creation of high-fidelity genetic modifications within a single generation, in contrast to the slow rates of progress and low success rates of traditional selective breeding techniques. Genetic engineering has already created crops with enhanced yields and reduced requirements for agricultural inputs, such as nutrients, water, fertilizer, herbicides, and pesticides. Similar results have been achieved with genetically enhanced livestock.

Golden Rice illustrates the great promise and power of genetic engineering to enhance the genetic traits of organisms. ${ }^{41}$ Although rice is the major source of calories for much of the world's population, ${ }^{42}$ its grains lack a nutrient vital to human health: beta-carotene (also known as provitamin A). A biological problem precluded the use of traditional genetic techniques: since beta-carotene is not produced in the rice endosperm (that is, the edible tissue of rice), ${ }^{43}$ traditional selective breeding was not an option. Rather, two plant biologists, Peter Beyer and Ingo Potrykus, realized that genetic engineering was necessary to introduce genetic traits where they previously did not exist.

Potrykus and Beyer discovered that the addition of two transgenes (i.e., genes from organisms other than rice) to the rice genome led to the production of beta-carotene in the endosperm:

The first transgene encodes phytoene synthase (PSY), which utilises the endogenously synthesised geranylgeranyl-diphosphate to form phytoene, a colorless carotene with a triene chromophore. The second encodes a bacterial carotene desaturase (CRTI) that introduces conjugation by adding four double bonds. The combined activity of

"[a] method for making a synthetic cell," "[a] synthetic cell," and, most comprehensively, "A method comprising: designing a synthetic genome; constructing the synthetic genome; introducing the synthetic genome into a biological system; and expressing the synthetic genome." U.S. Patent Application 20070264688, http://patft.uspto.gov (follow "Quick Search" under "Published Applications"; then search for "synthetic genomes").

40. NUFFIELD COUNCIL, supra note 38 , at 5 .

41 This discussion of Golden Rice genetics is adapted from Andrew W. Torrance, Intellectual Property as the Third Dimension of GMO Regulation, 16 KAN. J.L. \& PUB. POL'Y 257 (2007).

42. Golden Rice Humanitarian BOARD, THE SCIENCE Behind Golden Rice, http://www.goldenrice.org/Content2-How/how1_sci.html (last visited Aug. 9, 2008).

43. $I d$. 
PSY and CRTI leads to the formation of lycopene, which is a red compound due to its undecaene chromophore.

With the addition of these transgenes, rice endosperm is able to produce beta-carotene in significant amounts. ${ }^{45}$ Although the first generation of Golden Rice contained a PSY gene derived from daffodil and a CRTI gene derived from a bacterium, Erwinia uredovora, ${ }^{46}$ much higher amounts of beta-carotene were later achieved by inserting a PSY gene from maize. ${ }^{47}$ By 2005, the Golden Rice genetically engineered by Potrykus and Beyer was capable of producing sufficient beta-carotene to meet even the ambitious recommended daily allowances for children in rich, developed countries. ${ }^{48}$

Golden Rice sets into high relief a crucial difference between traditional selective breeding for genetic traits, on the one hand, and genetic engineering, on the other. The former can only yield organisms with heritable traits amplified from existing genes, and can only do so over multiple generations; where there is no genetic basis for a trait, that gene-based trait cannot be bred. Genetic engineering, by contrast, can create organisms with gene-based traits in organisms with no genetic basis for such traits, and can do so within a single generation.

\section{B. Genetic Engineering of Humans}

Though useful and widespread for more than thirty years as a technique for adding genetic traits to nonhuman organisms, genetic engineering was, until a decade ago, inapplicable to humans themselves. Even its successful application to a variety of fellow mammals did not justify its use in humans, largely for reasons of ethics. As Lee Silver, a geneticist at Princeton University, explains:

Since the 1980s, genetic engineering has been practiced with success in animals like mice, cows, sheep, and pigs. But it has yet to be applied to human beings for one simple reason-it is incredibly inefficient. With the simplest technique for adding genes to embryos, the success rate is 50 percent at best, and this is accompanied by a 5 percent risk of inducing disease-causing mutations in the animal that is born. That's not a problem for animal geneticists - who can choose the one healthy animal with a desired genetic modification from among a

\footnotetext{
44. Id. (citations omitted).

45. Id.

46. Id.

47. Id.

48. Id.
} 
litter or flock - but it is unacceptable for use with humans. And with more sophisticated techniques of gene alteration, the problem just gets worse, with only one cell in a million likely to be altered in the correct way.

However, the discovery of mammalian cloning has made genetic engineering much more feasible in humans by removing a number of the pre-cloning technical hurdles. Silver continues:

With such a low rate of success, the direct engineering of genes within an isolated human embryo-destined to be a child-is not something that anyone would try or accept. But with cloning, the entire equation changes. Now, multiple cells grown from a single embryo could be subjected to genetic engineering. With protocols already available today [in 1997], those that appear to be engineered as desired could be recognized and picked out. Each single selected cell could be expanded by itself into a clone of cells that provides sufficient material for the confirmation of genetic integrity. Then, and only then, would one cell from this mass of cells be used by means of nuclear transplantation to produce a new embryo, which would develop into a new human being, with a special genetic gift. Incredibly, within five months of the announcement of Dolly's birth, on July 25, 1997, the same team of Scottish scientists announced that they had successfully carried out this very protocol with the birth of several lambs carrying a foreign human gene. It is in the very same manner-when the techniques of cloning and genetic engineering are combined - that the human species will gain control over its own destiny. ...

Since the birth of Dolly, ethical concerns have shifted to focus less on rates of success for genetic engineering than on whether or not humans should be genetically engineered at all. The ability of human parents to select genetic traits for their children is now more a question of when rather than if.

\section{Genetic Enhancement of Humans}

Humans have always welcomed enhancements to their capacities, including those made possible by new technology. As Henry T. Greely points out:

The story of humanity is the history of enhancement. Stone tools, control of fire, and clothing all enhanced the success of hunter gatherers. Agriculture enhanced food supply and population size and

49. SILVER, supra note 2, at 129.

50. Id. at $129-30$. 
made possible the specialization of labor. Writing systems enhanced our ability to communicate, among people and across time, and strengthened our memories; printing reduced the costs of mass distribution of information. Metallurgy and engineering, electricity and computers have all increased what humans can do and what we can be. ${ }^{51}$

An often controversial category of enhancement is biological enhancement. $^{52}$ Biological enhancements "increase our abilities by enhancing our biological selves through new technical inventions." Examples of biological enhancement include plastic surgery that increases a recipient's physical attractiveness, caffeine that improves a recipient's ability to study late into the night, and anabolic steroids that accelerate a recipient's ability to acquire muscle mass.

While biological enhancement is controversial, genetic enhancement is especially so. Many people consider genetic engineering to enhance human beings unethical, immoral, or both. However, the human desire to improve is strong, and the desire to improve one's children permanently is an extremely powerful force. The capacity that somatic nuclear transfer, or cloning, has for genetic enhancement of one's offspring will be highly attractive to many parents. Parents, who tend to be especially fond of providing their own children with advantages, will be especially interested in making such enhancements permanent by engineering them into their offspring. Lee Silver offers the following prediction:

Genetic engineering will eventually be used by future reprogeneticists. It will begin in a way that is most ethically acceptable to the largest portion of society, with the treatment of only those childhood diseases-like sickle cell anemia or cystic fibrosis-that have a severe impact on quality of life. The number of parents who will desire this service will be tiny, but their experience will help to ease society's trepidation.

As the fear begins to subside, reprogeneticists will expand their services to nullify mutations that have a less severe impact on a child, or an impact delayed until adulthood. Predispositions to obesity, diabetes, heart disease, asthma, and various forms of cancer all fall into this category. And as the technology spreads, its range will be extended to the addition of new genes that serve as genetic inoculations against various infectious agents, including the HIV virus that causes

51. Greely, supra note 1 , at 88 .

52. See id.

53. Id. at 88 . 
AIDS. At the same time, other genes will be added to improve various health characteristics and disease resistance in children who would not otherwise have been born with any particular problem.

The final frontier will be the mind and the senses. Alcohol addiction will be eliminated, along with tendencies toward mental disease and antisocial behavior like extreme aggression. Visual and auditory acuity will be enhanced in some to improve artistic potential. And when our understanding of the genetic input into brain development has advanced, reprogeneticists will provide parents with the option of enhancing various cognitive attributes as well. ...

In the short term... most genetic enhancements will surely be much more mundane [than potentially extraordinary enhancements]. They will provide little fixes to all of the naturally occurring genetic defects that shorten the lives of so many people. They will enrich physical and cognitive attributes in small ways. And as the years go by over the next two centuries, the number and variety of possible genetic extensions to the basic human genome will rise exponentially.... Extensions that were once unimaginable will become indispensable ... to those parents who are able to afford them. ${ }^{54}$

Lee Silver envisions that the availability of genetic enhancement will have great effects upon society. In fact, he predicts the emergence of a social, political, economic, and even reproductive barrier between the genetically enhanced ("GenRich") and those without genetic enhancements ("Naturals"):

[A] difference has emerged [among humans] that is sharp and easily defined. It is the difference between those who are genetically enhanced and those who are not. The GenRich ... all carry synthetic genes. Genes that were created in the laboratory and did not exist within the human species until twenty-first century reproductive geneticists began to put them there. The GenRich are a [future] hereditary class of genetic aristocrats.

The future course of human genetic enhancement is unlikely to lead to a scenario exactly like that proposed by Lee Silver. Nevertheless, it is highly probable that genetic enhancement of some kind-whether narrow in scope and relatively uncontroversial in nature, such as ameliorating genetic diseases, or broader in scope and more controversial, such as expanding the potential abilities of humans beyond their non-genetically enhanced baselines — will occur in the near future.

54. SILVER, supra note 2, at 236-39.

55. Id. at 4 . 
Humans have attempted to enhance themselves for millennia. Enhancement is an unsurprising and rational goal because it confers, or is perceived to confer, advantages. Becoming faster, stronger, healthier, more attractive, or cleverer are all obvious temptations, especially in a society where competition can decide who receives scarce resources such as acceptance to prestigious schools, academic scholarships and awards, remunerative jobs, high social status, financial prestige, and desirable mates. Existing individuals might wish such enhancements for themselves, though successfully conferring the genetic traits that might undergird such enhancements would be technologically difficult. However, enhancing one's children would be far more feasible, even with existing biotechnology, since enhancing genes could be introduced into embryos early enough to ensure that all subsequent cells carry the enhanced genotype.

Parents will often make extreme efforts to ensure the success of their children, sometimes even sacrificing themselves in favor of their offspring's survival. If genetic enhancement were to raise the probability that their children might thrive in a highly competitive world, at least some, and probably many, parents would be willing to choose genetic enhancement for their children. Furthermore, if some parents chose to enhance their offspring, other parents, who might otherwise have opted not to enhance, would feel pressure to ensure that their own offspring did not begin life at a genetic disadvantage relative to the genetically enhanced children of other parents.

In the language of evolutionary biology, the strategy of not enhancing one's offspring while others enhance their offspring might be an unstable strategy. The societal implications could also be destabilizing. Philosopher Jürgen Habermas has observed that genetic enhancement of some but not others might threaten "the essentially symmetrical relations between free and equal human beings." $" 56$ However, in the likely absence of governmental intervention in reproductive decision-making, parents will perform the fearful calculus about whether or not to attempt to enhance their children genetically. Michael Sandel explains the stark choice that may face parents:

Pointing to the possible effects of bioengineering on humility, responsibility, and solidarity may be persuasive to those who prize those virtues. But those who care more about gaining a competitive edge for their children or themselves may decide that the benefits to be 
gained from genetic enhancement outweigh its allegedly adverse effects on social institutions and moral sentiments. ${ }^{57}$

As human genetic enhancement will almost certainly become a technological reality in the near future, it is vital to consider how the law will regulate access to it. Currently, although drug regulation laws may police the safety and efficacy of genetic enhancements intended for the market, it is the patent system that will largely determine who gains access to those genetic enhancements that are approved.

\section{PATENTS AND GENETIC ENHANCEMENT}

\section{A. The Patent System}

The Patent $\mathrm{Act}^{58}$ requires patent applications to satisfy several statutory requirements before they can become patents. Beyond a number of procedural requirements, there are several substantive requirements, principally those of novelty, ${ }^{59}$ nonobviousness, ${ }^{60}$ utility, ${ }^{61}$ disclosure, $^{62}$ and claims. ${ }^{63}$

Patents are expensive and take a long time to obtain. On average, an applicant for a patent pertaining to a complex technology will spend more than $\$ 11,000$ simply to file a patent application, ${ }^{64}$ and, after filing, considerably more to obtain enforceable patent rights. ${ }^{65}$ The examination procedure performed by the United States Patent and Trademark Office (USPTO), the agency where patent applications are examined by technically skilled examiners before a patent can issue, is relatively slow. Patent prosecution (the process through which a patent application must pass prior to issuance as a patent) generally takes from

57. Michael J. Sandel, The Case Against Perfection: Ethics in the Age of Genetic ENGINEERING 95 (2007)

58. 35 U.S.C. $\S 1(2000)$.

59. Id. § 102 .

60. Id. $\S 103$.

61. See id. § 101 (referring to a "new and useful process").

62. Id. $\S 112$.

63. Id.

64. Thomas C. Fiala \& Jon E. Wright, Preparing and Prosecuting a Patent That Holds Up in Litigation, 875 PLI/PAT 515, 521-22 (2006) ("For example, based on the AIPLA Report of the Economic Survey 2005, the average expected charge in 2004 for preparing and filing a utility patent application was $\$ 11,218$ for a relatively complex electrical or computer application and $\$ 12,373$ for a relatively complex biotechnology/chemical application.").

65. Interview with Craig Smith, Partner, Fish \& Richardson P.C. (Mar. 5, 2007). 
two and a half to five years, ${ }^{66}$ with the duration of prosecution rising with the complexity of the technology involved.

Once a patent is actually issued by the USPTO, the term of a patent is almost always significantly less than the theoretical twenty-year term because of time spent in patent prosecution or regulatory approval. Even with patent term extension to compensate for unreasonable federal agency review, the average enforceable lifetime of a patent lasts only about fifteen to seventeen and a half years. If a patent owner decides to enforce the right to exclude others from making, using, selling, offering to sell, or importing a patented invention, the average cost of patent litigation can rise above five million dollars, depending on the amount of damages at issue. ${ }^{67}$ Additionally, patent litigation involves a significant degree of unpredictability, at least in part due to the proliferation of judicial barriers and available defenses to patent infringement. ${ }^{68}$

Patent rights themselves have attracted an increasing amount of controversy among the public in recent years. This is especially true where gene patents are concerned.

66. Id. The USPTO Performance Report for fiscal year 2006 reports an average patent pendency time (defined as time from filing until patent issued or application abandoned by applicant) of 31.1 months and shows that this figure has been increasing over the past few years. U.S. PATENT \& TRAdemark OfFice, Performance AND ACCOUNTABILITY RePORT: FisCAL YeAR 200622 (2006), available at http://www.uspto.gov/web/offices/com/annual/2006/ 2006annualreport.pdf. However, the average pendency times estimated by the USPTO are likely underestimates. Kristen Osenga, Entrance Ramps, Tolls, and Express Lanes-Proposals for Decreasing Traffic Congestion in the Patent Office, 33 FLA. ST. U. L. REv. 119, 129-30 (2005) (" $[\mathrm{T}]$ he average prosecution (or pendency) time for an ultimately successful patent is 3.6 years, with a median of 2.7 years. Anecdotally, the time period from filing to issuance varies by technology and ranges from twenty-four to thirty-six months for chemical and mechanical arts and thirty-six to sixty months for electrical and software arts."),

67. Fiala \& Wright, supra note 64 , at 522 ("In comparison, the average estimated costs associated with litigating a patent in 2005 as reported by the [AIPLA Report of the Economic Survey 2005] were: $\$ 769,562$ for a patent infringement suit in which less than $\$ 1$ million was at risk; $\$ 2,637,179$ for a suit in which between $\$ 1$ and $\$ 25$ million was at risk; and $\$ 5,175,753$ for a suit in which more than $\$ 25$ million was at risk.").

68. See, e.g., David J.F. Gross \& Shawn T. Gordon, Claim Construction, Patent Infringement, and the Growing Importance of the Claim Vitiation Defense, 841 PLI/PAT 45, 51 (2005) ("This paper reviews the basic principles of claim construction and then discusses the current status of the doctrine of equivalents. As explained below, the Federal Circuit has erected several independent barriers to finding infringement under the doctrine of equivalents, but the most foreboding of such barriers may be the doctrine of claim vitiation."); Douglas R. Nemec, Current Trends in Equitable Defenses to Patent Infringement: Prosecution Laches and Inequitable Conduct, 804 PLI/PAT 1147, 1155 (2004) ("This article also compares several recent Federal Circuit decisions on inequitable conduct, and explores how these cases, together with Symbol Technologies, suggest an inclination by the Federal Circuit toward more vigorous policing and enforcement of the rules of conduct before the PTO."). 


\section{B. The Patent Quid Pro Quo}

Among the rights a patent confers to the patent owner is the right to exclude others from making, using, selling, offering to sell, or importing the claimed invention during the term of the patent, or from inducing or contributing to such infringement. ${ }^{69}$ The term of a patent lasts twenty years from the filing date or earliest priority date of a patent application. $^{70}$ In return for the limited monopoly right to exclude, an inventor must provide the public with a full disclosure of the claimed invention.

According to 35 U.S.C. $\$ 112$, a patent applicant must provide a detailed and explanatory disclosure of the claimed invention:

The specification shall contain a written description of the invention, and of the manner of making and using it, in such full and clear, concise, and exact terms as to enable any person skilled in the art to which it pertains, or with which it is most nearly connected, to make and use the same, and shall set forth the best mode contemplated by the inventor of carrying out his invention.

This disclosure requirement is often conceived of as part of a bargain between inventor and society. In return for monopoly rights to exclude others from making, using, offering to sell, or selling the patented invention within the United States, or importing the patented invention into the United States, ${ }^{72}$ the patentee contributes new information to the metaphorical public storehouse of knowledge. Although information about how to practice the claims is of limited immediate usefulness in the face of the patent owner's right to exclude others during the term of a patent, the teachings in a patent do provide society with new knowledge or techniques. These new teachings may help other inventors to develop other, unrelated inventions, improvements on the claimed invention, or noninfringing alternatives that directly compete with the claimed invention. ${ }^{73}$ In addition, once the patent term expires, so does the patent owner's right to exclude others from freely practicing the claimed invention. ${ }^{74}$ The disclosure requirement functions to assist in ensuring

69. 35 U.S.C. § 271(a)-(b) (2000).

70. Id. $\S 154(\mathrm{a})(2)$.

71. Id. $\S 112$.

72. Id. $\S 271(\mathrm{a})$

73. Note that these informational amenities all lessen the deadweight loss to society incurred by the monopoly exclusion rights conferred by the patent grant.

74. Id. $\S 154(\mathrm{a})(2)$ ("[the patent] grant shall be for a term beginning on the date on which the patent issues and ending 20 years from the date on which the application for the patent was filed in 
the fairness of the bargain made between inventor and society by ensuring that the public storehouse of knowledge receives reliable, new information $^{75}$ to justify toleration of the deadweight loss to society caused by the patent owner's monopoly exclusion right. As the Supreme Court has pronounced, the disclosure requirement is " the quid pro quo of the right to exclude." $" 76$

The first paragraph of 35 U.S.C. $\$ 112$ outlines the disclosure requirement. ${ }^{77}$ An applicant for a patent must provide "a written description of the invention." 78 This disclosure requirement has several purposes. First, it serves a notice function, by providing the public with a specific indication of what the inventor considers to be his or her invention. Second, the disclosure requirement represents the very core of the patent bargain, and is "arguably the most important patent doctrine after obviousness." ${ }^{79}$ It is crucial for ensuring that society receives an adequate description of inventions in exchange for tolerating the monopoly rights to exclude others granted to inventors. ${ }^{80}$ One of the paramount purposes of the disclosure requirement is

to provide the assurance that the public will, in fact, receive something in return for the patent grant. This consideration is, of course, the full and complete disclosure of how to make and use the claimed invention. Thus, the patent adds a measure of worthwhile knowledge to the public storehouse. The incentive to give this added measure of knowledge to the public, which clearly promotes the progress of the "Useful Arts," is the primary justification for the existence of the patent system. ${ }^{8}$

A patent application claiming a new gene (or any other invention) must disclose "the manner and process of making and using it, in such full and clear, concise, and exact terms as to enable any person skilled in the art to which it pertains, or with which it is most nearly connected, to

the United States"). See also id. §154(a)(1) (listing among the patent holder's rights the exclusion of others from using, offering, or selling the products made through the inventor's process).

75. A U.S. patent application is typically published around eighteen months subsequent to filing a patent application.

76. J.E.M. Ag Supply, Inc. v. Pioneer Hi-Bred Int'l, Inc., 534 U.S. 124, 142 (2001) (quoting Kewanee Oil Co. v. Bicron Corp., 416 U.S. 470, 484 (1974)).

77. 35 U.S.C. $\S 112(2000)$.

78. Id.

79. Enzo Biochem, Inc. v. Gen-Probe, Inc., 323 F.3d 956, 982 (Fed. Cir. 2002) (Rader, J., dissenting) (addressing the enablement requirement).

80. In economic terms, the enablement requirement, along with the written description and best mode requirements, may be viewed as attempts to minimize the deadweight loss to society attending the monopoly right to exclude conferred by a patent.

81. In re Argoudelis, 434 F.2d 1390, 1394 (Baldwin, J., concurring) 
make and use the same...." ${ }^{, 82}$ Furthermore, as explained in In re Wright, "[a]lthough not explicitly stated in section 112, to be enabling, the specification of a patent must teach those skilled in the art how to make and use the full scope of the claimed invention without "undue experimentation." $" 83$

\section{Promoting Progress in the Useful Arts}

Legal authority for a patent system is based within the United States Constitution. Specifically, Article 1, Section 8, Clause 8 states that the Congress shall have power " $[\mathrm{t}] \mathrm{o}$ promote the Progress of Science and useful Arts, by securing for limited Times to Authors and Inventors the exclusive Right to their respective Writings and Discoveries." ${ }^{84}$ Congress has relied on this explicit constitutional authority to offer statutory patent protection for inventions since the original Patent Act of $1790 .^{85}$

"[T]o promote the Progress of Science and useful Arts," the availability of patent protection provides an incentive for inventors to invest their valuable time and efforts on the development of technological innovations. By virtue of the monopoly right that a patent confers, investments in developing new and useful compositions, devices, and methods have an enhanced opportunity of yielding profits because inventors can exclude all others from making, using, selling, offering to sell, or importing their inventions for a substantial period of time. A particular advantage of this incentive system is that Congress need not offer inventors financial rewards for new inventions because, based on the right to exclude others, patent owners can directly extract monopoly rents from consumers wishing to make or use patented inventions. The monopoly pricing that the patent system allows does inflict a deadweight loss on society. However, the monopoly endures only for a limited period of time (i.e., twenty years from the filing date of a utility patent or PCT application), after which the right to exclude others is lost, and competition can drive down prices. Counteracting the deadweight loss to society, the disclosure of a patent application delivers informational benefits to society as soon as it is published (i.e., usually about eighteen months following the patent application's priority date). ${ }^{86}$

\footnotetext{
82. 35 U.S.C. $§ 112(2000)$.

83. 999 F.2d 1557, 1561 (Fed. Cir. 1993) (citations omitted).

84. U.S. CONST. art. I, $\S 8$, cl. 8 .

85. Act of Apr. 10, 1790, 1 Stat. 109 (1790).

86. See 35 U.S.C. $\S 122$ (b) (2000) (discussing how publication of a patent application generally
} 
The patent system is commonly assumed to promote scientific and technological progress. ${ }^{87}$ By conferring upon inventors a limited monopoly right to exclude others, the patent system is generally assumed to create incentives for scientific technical innovation additional to those incentives that would exist in the absence of available patent protection. The United States Constitution explicitly recognizes that the goal of the patent system is "[t]o promote the Progress of . . . useful Arts. ..." theory, potential inventors will respond to the incentive created by the patent system by choosing to allocate more time, energy, and other resources into inventing "any new and useful process, machine, manufacture, or composition of matter, or any new and useful improvement thereof" ${ }^{\prime 99}$ than would otherwise be the case but for the patent system.

The hypothesis that the patent system spurs innovation (the "Innovation Hypothesis") has been tested by both economists and legal scholars through a number of different approaches. Some of these have established theoretical frameworks to explain why the patent system should promote innovation. Others have attempted to estimate the additional quantum of innovation created by the availability of patent protection by using a number of distinct approaches: designing mathematical models of technological innovation; attempting directly to measure levels of innovation in a single economy; and comparing rates of innovation between countries offering strong patent protection and countries offering weak, or no, patent protection. Still others have questioned the basic assumption that the patent system does indeed promote innovation, suggesting, instead, that patents may lead to fewer inventions, at least under certain circumstances. Thus far, there is surprisingly little clear evidence that patent systems promote innovation.

The introduction to Patents in the Knowledge-Based Economy, ${ }^{90}$ a 2003 publication of the National Academies Press, discusses recent work addressing whether the theory is valid: "There are theoretical as well as empirical reasons to question whether patent rights advance innovation in a substantial way in most industries." $"$ F1 For example, the benefit of the

occurs approximately eighteen months after the filing date of the patent application).

87. Here, "scientific and technical" are intended to be interpreted broadly to include all fields susceptible of patent protection, including biological, chemical, physical, electrical, mechanical, software, athletic, business, and financial innovations.

88. U.S. CONST. art. I, $\S 8$, cl. 8.

89. 35 U.S.C. $\S 101(2000)$.

90. Wesley M. Cohen \& Stephen A. Merrill, Patents in the Knowledge-Based ECONOMY (Wesley M. Cohen \& Stephen A. Merrill eds., 2003).

91. Id. at 2 . 
patent monopoly might be outweighed by the cost of the disclosure the patent system requires, ${ }^{92}$ and "where technological advances build upon one another cumulatively, as is increasingly the case, broad patent protection on upstream discoveries may slow the rate of technical change by impeding subsequent innovations." 93 On the whole, the authors argue, the "literature on the impact of patents on innovation must be considered emergent." 94 There has been "little systematic empirical analysis of the impact of patents on innovation." limited data in some areas; another is that "the effect of patent policy has many dimensions" and it has therefore been challenging to determine how a particular policy actually affects innovation. ${ }^{96}$

Mazzoleni and Nelson provide a useful framework for organizing theories about the patent system. They suggest that the answer to the question, "What are the social benefits and costs of awarding patents for inventions?" is not simple or well settled (though "[m]any economists and patent lawyers seem to think" that it is). ${ }^{97}$ They propose four broad theories about the purposes served by patents:

1. The anticipation of patents provides motivation for useful invention: we will call this the "invention motivation" theory.

2. Patents induce inventors to "disclose" their inventions when otherwise they would rely on secrecy, and in this and other ways facilitate wide knowledge about and use of inventions: we will call this the "invention dissemination" theory.

3. Patents on inventions induce the needed investments to develop and commercialize them: this we call the "induce commercialization" theory.

4. Patents enable the orderly exploration of broad prospects: we call this the "exploration control" theory.

The authors recognize that these purposes are not necessarily mutually exclusive, and may overlap, but some versions of the theories do conflict. The first three theories have a long history, whereas the

92. Id.

93. Id. at 3.

94. Id.

95. Id. at 2.

96. Id. at $3-4$.

97. Roberto Mazzoleni \& Richard R. Nelson, Economic Theories About the Benefits and Costs of Patents, 32 J. ECON. IssuEs 1031, 1031 (1998).

98. Id. at 1033 . 
fourth theory is of relatively recent vintage. ${ }^{99}$ The authors also make the useful observation that theories about the costs and benefits of patents are often based on assumptions (not always explicit) about certain "context conditions":

1. The nature and effectiveness of means other than patents to induce invention and related activities. These "other means" may be as diverse as government grants and contracts or strong first mover advantages.

2. Whether the group of potential inventors is likely to work on diverse and non-competing ideas, or whether the group is likely to be focused on a single alternative or a set of closely connected ones. Basically the issue here is whether or not more inventing input yields more useful inventing output or mainly duplication of effort and waste.

3. The deterrent effect of the presence of patents on unauthorized use of a technology and on the transaction costs involved in licensing an invention.

4. Whether the multiple steps in the invention, development, and commercialization of a new technology tend to proceed efficiently within a single organization, or whether efficiency is enhanced if different organizations are involved at different stages of the process.

5. What we will call the topography of technological advance, by which we mean the manner in which inventions are linked to each other temporally, and as systems in use.

At least some of these conditions are partly endogenous to the nature of the patent system. They are themselves influenced by the strength and scope of the patent protection within a field of technology.

... In any case, the implications of the theories are very sensitive to the assumed context conditions. ${ }^{100}$

Later, they make the point that different theories probably apply in different domains: "The proposition we now want strongly to espouse is that the appropriate question about these diverse theories is not 'Which theory is the correct one?' but rather, 'Where do the different theories apply?",101 However, the empirical work necessary to answer this question has not yet been done.

99. Id.

100. Id. at $1033-34$.

101. Id. at 1044. 
Numerous other approaches have been taken to analyze the question of what effects patents have on promoting or retarding innovation. For example, Landes and Posner suggest a theoretical approach that incorporates insights from other forms of intellectual property law: "a more illuminating way of thinking about the patent system is as a response to economic problems inherent in trade secrecy and market structure." 102 Much more work will be required before stronger causal links can be drawn between patents and innovation. In the meantime, existing empirical evidence does suggest that the patent system can be effective at generating genetic innovation in general. In this respect, the relationship between patents and genetic innovation may be an exception.

\section{Promoting Progress in the Genetic Arts}

In 1998, Michael Heller and Rebecca Eisenberg raised the specter that patents claiming genes risked causing a "tragedy of the anticommons":

[T]he recent proliferation of intellectual property rights in biomedical research suggests... an "anticommons" in which people underuse scarce resources because too many owners can block each other... [Unless privatization of biomedical research is managed properly] more[intellectual property] rights may lead paradoxically to fewer useful products for improving human health.

Heller and Eisenberg envisioned a particular risk of incurring a tragedy of the anticommons with respect to patents claiming genes, fragments thereof, or polypeptides. ${ }^{104}$ Without careful limitation of patents on such categories of inventions, Heller and Eisenberg feared the creation of "a tragedy of the anticommons through a proliferation of fragmented and overlapping intellectual property rights." ${ }^{\prime 105}$ Subsequently, others have also suggested that patents claiming genes might inhibit, rather than promote, genetic innovation. ${ }^{106}$

102. William M. Landes \& Richard A. Posner, The Economic Structure of INTELLECTUAL PROPERTY LAW 294 (2003).

103. M. Heller \& R. Eisenberg, Can Patents Deter Innovation?: The Anticommons in Biomedical Research, 280 SCIENCE 698-701 (1998).

104. Id. at 699 .

105. Id. at 701 .

106. E.g., Gaia Vince, Gene Patents "Inhibit Innovation", New SCIEnTIST, July 23, 2002, http://www.newscientist.com/article.ns?id=dn2580 (reporting conclusion of the Nuffield Council on Bioethics' discussion paper on gene patents). 
However, a tragedy of the anticommons in gene patents has been difficult to substantiate. To the contrary, the best available evidence appears to discount its existence. Caulfield et al. have summarized the evidence:

The results of [surveyed] empirical efforts have been fairly consistent. First, the effects predicted by the anticommons problem are not borne out in the available data. The effects are much less prevalent than would be expected if its hypothesized mechanisms were in fact operating. The data do show a large number of patents associated with genes. A recent study found that nearly $20 \%$ of human genes were associated with at least one US patent, and many had multiple patents. Another study estimated that in the United States over 3,000 new DNA-related patents have issued every year since 1998, and more than 40,000 such patents have been granted. But despite the large number of patents and the numerous, heterogenous actors-including large pharmaceutical firms, biotech startups, universities and governmentsstudies that have examined the incidence of anticommons problems find them relatively uncommon. These studies span both academics and industry, and include data from the United States, Germany, Australia and Japan. ${ }^{107}$

As the authors conclude, "although there may have been good reasons for concern, the feared problems [predicted to be caused by the tragedy of the anticommons] have not widely manifested."108 Similarly, a recent comprehensive survey of human gene patent litigation in United States courts concludes that gene patents have not caused a tragedy of the anticommons in the United States. ${ }^{109}$

In their recent study of the role that the patent system plays in spurring innovation, James Bessen and Michael J. Meurer suggest the patent system may indeed promote innovation in the pharmaceutical/biotechnology industry. ${ }^{110}$ As Bessen and Meurer have stated, "The evidence certainly is consistent with the notion that patents encourage American pharmaceutical R \& D."111

107. Timothy Caulfield et al., Evidence and Anecdotes: An Analysis of Human Gene Patenting Controversies, NATURE BIOTECHNOLOGY 1091, 1092 (2006).

108. Id. at 1093.

109. Christopher M. Holman, The Impact of Human Gene Patents on Innovation and Access: A Survey of Human Gene Patent Litigation, 76 UMKC L. REV. 295, 361 (2007).

110. James Bessen \& Michael J. Meurer, Patent Failure: How Judges, Bureaucrats, AND LAWYERS PUT INNOVATORS AT RISK 16 (2008).

111. Id. 


\section{E. Exclusion from Genetic Enhancement}

By conferring on their owners the right to exclude parents from access to genes that could enhance their children, gene patents have powerful implications for the distribution of genetic enhancement within society. In essence, the right to exclude may bar at least some parents from the opportunity to genetically enhance their children. Like more conventional drugs and other medicines, access to genetic enhancements would likely be mediated through pricing mechanisms. The more valuable the enhancement a gene offered, the more expensive access to that gene would be for parents eager to ensure the best genes for their children.

It is true that the right to exclude tends to last for only twenty years from the filing date of the patent application, resulting in free access to any gene after its corresponding patent expires. However, just as with other rapidly-advancing fields of technology, genetic enhancements too will surely improve rapidly over time. As a consequence of such advances, a genetic enhancement that was once cutting-edge may become obsolete, or even positively deleterious, by the time its patent protection expires. In fact, it would be unsurprising if improvements in genetic enhancement advanced at least in part in order to surmount prevailing levels of genetic enhancement; a genetic enhancement shared by many or all depreciates any relative advantage conferred by that enhancement. One might even expect a sort of genetic enhancement arms-race to ensue, with those possessing sufficient resources opting to arm their children with the latest and greatest genetic enhancements to maintain their advantages over children with no, or lesser, genetic enhancements.

It is not difficult to imagine how the patent system could assist in achieving a division between GenRich and Naturals. In fact, by its mediation of access to genetic enhancements, patent law holds the potential to affect the future course of human evolution. Patent law could act as a direct force for differentiating genetically enhanced humans from those lacking genetic enhancements via two distinct mechanisms: (1) creating an incentive to discover, synthesize, and/or develop new genetic enhancements; and (2) by limiting access to those genetic enhancements.

\section{CONCLUSION}

Patent protection for genetic enhancements would tend to spur genetic innovation, but would tend to limit access to those genetic 
enhancements through discriminatory mechanisms such as price and favoritism. The patent system would likely ensure high rates of genetic enhancement innovation, research, and development, efficiently mediate access to genetic enhancements, but would also likely allow access to genetic enhancements to fewer members of society. Most importantly, the patent system has the potential to promote the kinds of genetic enhancements that might lead to human evolutionary change.

Public policy and the law must grapple with the implications of genetic enhancement before current technological possibilities become societal realities. The patent system is an odd candidate to become a substantial arbiter of parental decisions regarding genetic enhancement of their offspring. It is certain that the implications the patent system has for future human genetic enhancement should be subjected to thorough analysis and debate prior to the imminent arrival of human genetic enhancement technologies. Otherwise, patent law may drive human evolution in directions either unplanned - or worse - undesired. 